\title{
Teaching in Higher Education: Theories, Realities and Future Controversies
}

\author{
Katerina R. Toka ${ }^{1}$, Labrina Gioti ${ }^{2}$ \\ ${ }^{1} \mathrm{PhD}$ Candidate, School of Primary Education, Aristotle University of Thessaloniki, Greece \\ ${ }^{2}$ Asst. Prof., School of Primary Education, Aristotle University of Thessaloniki, Greece \\ Correspondence: Katerina R. Toka, PhD Candidate, School of Primary Education, Aristotle University of Thessaloniki, \\ Greece.
}

Received: April 13, 2021

doi:10.11114/jets.v9i6.5210
Accepted: June 6, $2021 \quad$ Online Published: June 7, 2021

URL: https://doi.org/10.11114/jets.v9i6.5210

\begin{abstract}
The purpose of this paper is to investigate the field of University Pedagogy and specifically the relationship between theory (learning theories university teachers adopt) and practice (actual teaching) in Higher Education Institutions. To this end, we conducted a mixed methodology research (triangulation) by implicating both the students and the university teachers of post graduate programs of the former Alexander Technological Educational Institute-ATEI-of Thessaloniki (current International Hellenic University-IHU). The data collection methods were:7 semi-structured interviews with the teaching staff, student questionnaires $(\mathrm{n}=98)$ and non-participatory observation. Results show that teachers' views about learning and teaching are consistent mostly with person-centered humanistic learning theories and cognitive constructivism. Learning is viewed as a dynamic process revolving around students and their needs. Their student-centered approach and the theories they embrace are consistent with their teaching practice to a satisfactory degree (role, climate, teacher-student relationship, objectives, connection to reality). However, an issue detected is the relatively limited use of the most active teaching techniques.
\end{abstract}

Keywords: university pedagogy, Higher Education, student-centered learning, teaching practice, adult education, adult learning theories

\section{Introduction}

In recent years, there has been a convergence between the fields of University Pedagogy and Adult Education regarding the principles that govern them, their goals and the methods they adopt. Adult learning theories may be broadly categorized based on the emphasis on the learning procedure as teacher-centered and student-centered (Gioti, 2019b). Traditionally, teacher-centered learning prevailed in higher education programs even if it was associated with humanistic, progressive and radical worldview constructions about adult education and learning. The need for a shift towards student-centered learning in higher education has been explicitly stated by the EU, scholars and students (EHEA, 1999, 2009, 2012, 2015; HQA 2017; Kedraka \& Rotidi, 2017; Pavlakis, Talias \& Zannetos, 2013; Osman, Jamaludin \& Iranmanesh, 2015; Sursock, 2015; Smart, Witt \& Scott, 2012). As a consequence, teaching (undergraduate, postgraduate, or adult $25+$ students) should focus on the learner and promote active and collaborative learning, critical thinking, learner autonomy and responsibility, skills development, adoption of new attitudes (Gougoulakis et al., 2020; Connell, Donovan \& Chambers, 2016). Students in higher education institutions should be now treated as adults (Halx, 2010). As such, they have characteristics (autonomy, experiences, self-determination, sense of perspective, specific goals) (Knowles, 1990) and the ability to be profoundly transformed through learning (Brookfield, 2017; Mezirow, 2009) that require educational approaches and methods that satisfy their needs (Lynch \& Pappas, 2017; Pavlakis et al, 2013; Rogers, 1999).The last decades in the relevant bibliography the prevailing humanistic and constructivist theories are all student-centered and emphasize the learning dimensions mentioned above (Gioti, 2019a, 2019b).

The foregoing constitute the theoretical framework and the objectives set for Higher and Adult Education (EHEA, 1999; EHEA, 2012; EHEA, 2015). But are they practically feasible in international and Greek reality? How do Greek university teachers apply pedagogy and how do their students perceive their practice? How is theory applied into practice? Does teaching comply with the principles mentioned above?

It should be pointed out that the research is conducted in a specific context (national and educational) which should be 
analyzed in brief in order to help the reader gain perspective and interpret the findings accordingly. The operation of internal structures supporting the teaching and pedagogic work of university teachers is common among university institutions internationally. Ernest Boyer's (1990) report titled "Scholarship Reconsidered: Priorities of the Professoriate" played a pivotal role in the evolution of University Pedagogy. He conducted national research in 1989 with teaching and research staff members. Evident in his report is an alarming teacher emphasis on research and not on teaching though the latter is considered more-if not most-important. Since then, many universities have created Teaching and Learning Centers that assist and support the teaching, pedagogic and advisory work of university teaching staff.

In Greece however, the first relevant office was created in 2011 at the University of Patras (law 4009/2011-article 51) while the formal establishment and operation of Centers for Teaching and Learning in just three Greek universities (University of Patras, Democritus University of Thrace and Aegean University) only took place in 2020, 2019 and 2020 respectively (FEK 1832/13.05.2020; FEK 2468/24.06.2019; FEK 3933/15.09.2020). Moreover, the Network of Tertiary Education Teachers was created (2016) as a result of a relevant symposium, having as a purpose the development and diffusion of University Pedagogy. Finally, the first Greek Conference on University Pedagogy was held in 2019 under the aegis of Democritus University of Thrace.

It becomes evident that the issue of University Pedagogy is relatively new in Greece and as a result there are scant references regarding the relationship between theory (opinions, theories teachers adopt) and practice (teaching and practice-methods they actually use). The present research was conducted in the former Alexander Technological Education Institute (ATEI) of Thessaloniki (present International Hellenic University-IHU since 2019 when Law 4610/2019 incorporated Technological Educational Institutes-TEIs into existing Higher Education Institutions according to the directions of European Community policies).

The purpose of the research is to highlight the learning theories that guide university teachers' teaching practice. There will also be an attempt to explore whether and how their beliefs and opinions are transferred to how they practice teaching and perform their role. The paper also aspires to build on the limited existing knowledge on the issue of University Pedagogy in the Greek context and help stakeholders identify the challenges that arise within it.

\section{Theoretical Framework}

\subsection{Learning Theories for Teaching Adults}

Adult learning theories are humanistic, student-centered and constructivist in that they focus on learners' personal growth (humanistic), place students at the center of the learning process, promote active and collaborative learning (student-centered) and equate learning with creating meaning from experience and in relation to society and the surrounding world (constructivist). Learning in this context is a dynamic process that activates learners' learning abilities and builds on their personal experience (Rogers, 1999). However, within these classifications, there are significant differences in each theory's scope on how the construction of knowledge is approached and consequently on how the relationship between the individual, learning, and society is constructed/formulated. Based on scope we may identify 3 categories: 1) person-centered, 2) progressive and 3) critical/radical humanistic learning theories (Gioti, 2010). In respect to the knowledge construction process we may discern theories between cognitive and social constructivist.

Person-centered humanistic theories view learning as a personal and psychological phenomenon and have as a goal the learners' personal development and change. They do not acknowledge the influence society has on learners and they view learning as a process experienced in isolation. Progressive humanistic theories aim for a progressive change in society (as represented by Jarvis and Mezirow), whereas critical/radical humanistic theories (as represented by Freire and Brookfield) aim for profound and drastic societal changes and take on an activist role. Critical/radical humanistic theories support that learning does not happen in a vacuum and that it is not an individually experienced process; on the contrary, society and all its constituents (conditions, injustices, culture, ideologies and their social and political manifestations) deeply affect learning and the way people use knowledge to change their lives for the better (Gioti, 2010; Freire, 2005, 2018; Brookfield, 2017, 2005).

Constructivism has its roots in the works of Piaget Bruner and Goodman (Perkins, 1991). It questions objectivism and approaches learning as a meaning making process which is created from experience and affected by context and previous learning (Ertmer \& Newby, 1993; Bada \& Olusegun, 2015). Cognitive constructivism emphasizes the developmental process by which an individual constructs knowledge actively during her interaction with the environment in order to adapt to it. This process is perceived as happening in isolation from the social and cultural context ignoring how decisively it is defined by them. Social constructivism, based on the work of Russian psychologist Lev Vygotsky, adopts a social perspective and emphasizes the importance of social and cultural factors in the creation of knowledge, in the learning process and in the individual's development (Illeris, 2016; Trent, Artiles \& Englert 1998; Stetsenko \& Arievitch, 1997). Social constructivism underlines the impact society and its forces have on the way we 
learn and construct our understanding of the world. As Illeris (2016) aptly appoints, learning and other mental processes are not solely social or solely individually born; they are both.

Popular adult education scholars, among the different learning theories categories, are Knowles who introduced andragogy in the late 60 's and during the 70 's, Freire who in the same period developed his liberatory pedagogy, Mezirow who initiated the transformative learning theory in late 70's and Jarvis who provided a sociocultural and humanistic synthetic approach of the above that was presented in 1987.

Knowles' andragogy offers a humanistic approach to adult education. It is composed of six assumptions about adult learning: Adults a) need to know why they learn something b) must be treated as capable and self-directed, c) have a plethora of experiences and d) a life-centered orientation to learning and want knowledge relevant and applicable to their everyday lives, e) are mostly driven by intrinsic motivation and f) need to attend educational programs designed according to their needs (Knowles, 1990, 2005; McGrath, 2009; Tennant, 1986). Andragogy is influenced by american psychological imperialism, a phenomenon that approaches and interprets learning as a purely psychological process, disregarding the environment and the influence the latter has on learners and the learning process (Gioti, 2019a).

Freire's liberatory pedagogy is a radical humanistic theory that emphasizes the importance of the "populations' education". Its goal is to empower the socially subordinated by the ruling classes so that they detect the forces that oppress them, act against them in order to change society, and fulfill their potential. He claimed that there is no such thing as neutral adult education. Education either conforms to dominant dictates or leads to liberation and emancipation and consequently to the change of social structures. Dialogue and communication, vital in Freire's pedagogy, aim at critical consciousness or 'conscientization' (conscientização) which focuses on helping students comprehend that their living conditions and the uncritically assimilated ideas of the dominant culture are responsible for their 'culture of silence'. Critical reflection through which distorted and erroneous perceptions (about oneself and their relationship with others and society) are revealed and action as an intervention in order to change reality, constitute integral parts of critical consciousness. For Freire education is an act of freedom and liberation only when it takes place through dialogue and communication (Freire, 2018, 2005, 2000; Leonard \& McLaren, 2002).

Mezirow's transformative learning theory supports that the way we perceive and interpret reality is defined by our belief system. The goal of adult education is to make learners review their assumptions and challenge their validity through critical reflection, an ability that increases as a person gets older. A disorienting dilemma/trigger event leads to the revision of certain wrong/dysfunctional assumptions. Thus, learning is not just the addition of new knowledge but also the transformation of existing knowledge into a new perspective. Adults can achieve this transformation when through critical and autonomous reflection realize how and why their assumptions/perceptions confine the way they realize, perceive and feel the world around them (Mezirow, n.d. 1981, 1990, 2009). There are two main trends present in Mezirow's theory. The first focuses on the psychological dimensions of learning which is manifested in personal empowerment and change as an adjustment in existing conditions. The second trend is social and focuses on the empowerment that leads to action that transforms social conditions. In other words, in the first case learners adopt new perspectives and change the way they act without changing however the context within which this action takes place. They just modify their behavior leaving existing social structures unscathed. In the second case, people do not just accommodate to society but act in order to change it and make it more open, fair and democratic (Gioti, 2019a, 124-5).

Jarvis $(2004,2009$, 2012) provides an experiential learning theory as a synthesis of existing sociologically and psychologically oriented theories. His theory is progressive in that it aims at gradual societal change and not at drastic and profound changes. His approach views humans as acting subjects being in constant interaction with the environment. The learning process lies at the heart of human existence and is not neutral; it does not happen in a vacuum but under the influence of the socio-cultural assumptions/positions held both by educators and learners. Adult educational programs should grant learners some power and allow active participation in the learning process.

Theorists agree that adult education does not just concern the transmission of knowledge, but also the acquisition of skills that enable learners to reflect, challenge and adapt their attitudes. Change-whether personal or societal-is presented as an important aspect of adult education and is inextricably linked to the environment and its effects on humans. In addition, all theories consider learners' active involvement, collaboration, autonomy and reflection as essential components of effective learning. They therefore agree on the use of specific methods (participatory and heuristic, focused both on the group and the individual) and techniques (discussion, questions, teamwork, case study, role playing, simulation, games, hands-on training) that promote active participation (Rogers, 1999). In this context, university teachers' role is also changing. They are no longer authority figures but facilitators and partners, who interact with students in terms of equality and respect in an environment of security and freedom of expression.

\subsection{University Pedagogy}

The influence of adult education in University Pedagogy resulted in a growing research interest-both nationally and 
internationally-concerning the teaching/learning process in the universities. Specifically, research emphasizes on teachers' and students' views on quality teaching and learning and their affecting factors, the teacher's role, the student-teacher relationship, the theories teachers adopt and the way they practice them.

Several studies (Frementiti, 2018; Prosser \& Trigwell, 2014; Uiboleht, Karm \& Postareff, 2018) classify teaching into two categories:1) knowledge/information transfer (teacher-centered) and 2) knowledge support/conceptual change (student-centered). Research findings show that students support the need for a student-centered teaching approach with the adoption and application of teaching techniques that promote interaction, encouragement and self-development (Osman et al., 2015; Su\& Wood, 2012). Students also propose that university teachers must possess satisfactory organization and communication skills and excellent knowledge of their subject, must motivate students to actively participate in the learning process, provide constant feedback, clarify the tasks, connect old and new knowledge, be enthusiastic, supportive and inspiring (Alghamdi et al., 2017; Alhija, 2017; Asio \& Riego de Dios, 2018, 2019; Nitsiou, 2018; Trammell \& Aldrich, 2016; Su\& Wood, 2012). On the other end, teachers view themselves as facilitators who motivate and support their students. However, they use methods and techniques (lecture most frequently used) that focus on the teacher and are not appropriate for teaching adults (Dole, Bloom \& Kowalske, 2016; Nitsiou, 2018; Pavlakis et al., 2013; Stearns, 2017; Tzotzou \& Bigilaki, 2013), whereas research shows that only those teachers who use active teaching techniques, influence learners' engagement (Almarghani \& Mijatovic, 2017).

In Greece, university teachers are axiomatically considered pedagogically competent. It is a view not disputed, not challenged. University teachers are judged by their research and academic work and not by their pedagogical work (Gougoulakis, et al, 2020). It is considered self-evident that academic competence equals pedagogic competence (Asonitou, 2016; Gougoulakis \& Oikonomou, 2014; Gougoulakis, 2016; Kedraka \& Dimasi, 2015; Kedraka, 2016; Kedraka \& Rotidi, 2017; Vergidis, 2016).

An increasing research interest about University Pedagogy in Greece has been observed very recently, just in the last five years (Frementiti, 2018; Ioakeimidou et al., 2015; Nitsiou, 2018; Pavlakis et al, 2016; Rotidi \& Karalis, 2014; Rotidi, 2015; Tzotzou \& Bigilaki, 2013).This interest is in accordance with the efforts of the EU (EHEA 1999,2012,2015) to highlight the importance of improving the academics' teaching skills and focusing on the teaching/learning process and to attempt a transition from traditional teacher-centered teaching to a student-centered teaching approach with pedagogical principles, methods, and practices that promote reflection, learner engagement, autonomy and responsibility. The above are characteristics of adult education and indeed it is becoming evident that university students should be considered and treated as adults (Halx, 2010) and that Higher education promotes in essence the ideals and methods of adult education (EHEA, 2012, 2015; EHEA, 1999; HQA 2017; Kedraka \& Rotidi, 2017; Pavlakis et al., 2013)

\section{Methodology}

\subsection{Research Design}

Our paper presents part of the data of a mixed methodology research (qualitative and quantitative) conducted among students and teachers of the former ATEI of Thessaloniki (present IHU) in 2019-2020 which is an institution that offers a variety of postgraduate programs to adults (25+). The data collection tools were: student questionnaires (98), teaching staff interviews (7) and non-participatory observation. Our goal was to investigate the theories that university teachers adopt and their perception of learning and teaching in relation to their teaching practices.

The research questions were the following:

(1) What basic learning theories do the teachers of the programs adopt (views on learning, education, quality teaching, teachers' role)?

(2) Do their beliefs and attitudes fit into their teaching practice?

3.2 Sample

The population of our quantitative research was students $(\mathrm{n}=380)$ of three postgraduate programs. The sample was chosen with convenience, non-probability sampling (Bryman, 2016).

The qualitative research was carried out on a homogeneous purposive sampling. We conducted seven (7) semi-structured interviews with teachers of three postgraduate programs of the department of Business Administration, Marketing and Tourism. The sample was purposeful, and its selection met the following criteria: all participants are permanent members of the teaching staff, they all teach to postgraduate adult education programs $(+25)$ and they teach in soft disciplines ${ }^{1}$ (Lindblom-Ylanne et al., 2006; Lueddeke, 2003; Rotidi \& Karalis, 2014; Rotidi, 2015). We sent the

\footnotetext{
${ }^{1}$ According to Biglan's (1973) classification the academic disciplines may be Hard and Soft, Pure and Applied fields. In our study the term Soft disciplines includes the fields of Sociology, Linguistics, Philosophy, Economics, Educational
} 
interview to a total of 16 university teachers of whom 7 responded. To analyze research material we used the method of content analysis. The composition of the university's teaching staff as far as gender and ethnicity are concerned is not diverse. The absolute majority is Caucasian (also the case in most-if not all-Greek tertiary institutions) and the vast majority (76\%) are male teachers. The under-representation of women in the body of university teaching staff-especially in the rank of the professor-is a reality not only in Greece but in the European Union as a whole (EKT, 2020).

According to our research design, our intention was to conduct classroom observations of all teachers participating in the research $(n=7)$. However, due to COVID-19 restrictions, campuses suspended their operations and lessons were transferred to online teaching platforms. As a result, we were able to conduct one classroom observation.

\subsubsection{Interviews}

The answers to the interviews came exclusively from male teachers, with male/female ratio being 3:1 (Table 1).

Table 1. Profile of the teacher participants

\begin{tabular}{lllll}
$\begin{array}{l}\text { Interview } \\
\text { Subject }\end{array}$ & Age & $\begin{array}{l}\text { Teaching } \\
\text { experience } \\
\text { IHU(in years). }\end{array}$ & $\begin{array}{l}\text { Postgraduate } \\
\text { at Program** }\end{array}$ & Expertise/Training \\
\hline S1 & 46 & 10 & H.C.U.M./MBA & \\
\hline S2 & 40 & 18 & M.O.E.U./MBA & Adult Education \\
\hline S3 & 62 & 11 & M.O.E.U. & Adult Education \\
\hline S4 & 55 & 17 & T.M.B.A. & Teaching for Special Purposes \\
\hline S5 & 40 & 12 & H.C.U.M./M.O.E.U./M & \\
\hline S6 & 44 & 10 & M.A. & Adult Education \\
\hline S7 & 64 & 31 & T.M.B.A./M.M.L.I.S & Educational Methodology \\
\hline
\end{tabular}

${ }^{* *}$ H.C.U.M.:Health Care Units Management

M.O.E.U.:Management and Organization of Educational Units

T.M.B.A.:Tourism Management and Business Administration

\section{M.B.A.:M.Sc. In Business Administration}

M.M.L.I.S.:Money Management, Logistics and Informational Systems

\subsubsection{Questionnaires}

The sample of the research consisted of students $(\mathrm{n}=98)$ of three postgraduate programs of the ATEI. The response rate to the questionnaire was $25,8 \%(\mathrm{n}=98)$. Demographic and program attendance data are presented in Table 2 . The majority of participants $(\mathrm{n}=96)$ work.

The statistical processing of data was performed with the SPSS17, making use of both descriptive techniques and deductive statistics. The reliability of the survey was tested with a coefficient of internal consistency, Cronbach's alpha. Two composite variables were created:1) 'Learning Experience' (Knowledge, skills, attitudes) (0.904) and 2) 'Actions and attitudes of teaching personnel' (0.924). The level of reliability of both variables is high, so the internal consistency is considered very satisfactory.

Sciences and Law), that are related primarily with the adoption of a student-centered teaching perspective while the Hard/Soft and Applied fields such as Sciences, Mathematics, Dentistry, Medicine, Computer Engineering and Informatics are dominated mostly by a teacher-centered teaching perspective (Transmission) (in Rotidi, 2015 and Rotidi \& Karalis, 2014). 
Table 2. Profile of the postgraduate student participants

\begin{tabular}{|c|c|c|c|c|c|}
\hline \multirow[t]{2}{*}{ Sex } & \multicolumn{2}{|l|}{ Men } & \multicolumn{3}{|l|}{ Women } \\
\hline & $29(29.6 \%)$ & & $69(70.4 \%)$ & & \\
\hline \multirow[t]{2}{*}{ Age } & $25-34 y$ & & $35-44 y$ & $45-54 y$ & $55+y$ \\
\hline & $28(28.6 \%)$ & & $37(37.8 \%)$ & $27(27.5 \%)$ & $6(6.1 \%)$ \\
\hline \multirow[t]{2}{*}{ M.Sc. } & $\begin{array}{l}\text { Management } \\
\text { Organization } \\
\text { Educational Units }\end{array}$ & $\begin{array}{l}\& \\
\text { of }\end{array}$ & $\begin{array}{l}\text { Health Care Units } \\
\text { Management }\end{array}$ & $\begin{array}{l}\text { Tourism N } \\
\text { Administra }\end{array}$ & $\begin{array}{l}\text { nagement and Business } \\
\text { on }\end{array}$ \\
\hline & $49(50 \%)$ & & $37(37.8 \%)$ & & $2.2 \%)$ \\
\hline
\end{tabular}

\subsection{Data Gathering Procedure and Analysis}

The data compilation was done using a Questionnaire (quantitative research), interview questions and an observation grid (qualitative research) as tools. Questionnaire and Interview data were collected with Google Forms. Both the Questionnaire and the interview questions were constructed based on various sources namely: The Teaching Perspectives Inventory-TPI of (Collins \& Pratt, 2011; Pratt \& Collins, 2000; Pratt et al., 2001), the Course Experience Questionnaire-CEQ (Stergiou \& Airey, 2012) and questionnaires from Greek researchers (Bantiou, 2014; Nitsiou, 2018; Nikolakoudis, 2016; Rotidi, 2015).

An observation grid was created for the observation, based on a synthesis of observation tools: Pasiardis Assessment Form (Pasiardis, 2001), Flanders'Systematic Observation System (Magos, 2005) and Grift Assessment Tool (2007).The observation lasted two hours. The educational meeting that constituted the object of the observation was part of the 'Health Care Units Management' postgraduate program. The course's title was 'Management of Health Care Units' and the subject of the meeting was motivation. The number of students attending was approximately 70 .

\section{Results}

The research aimed to investigate which learning theories guide university teachers' practice. Our discussion of the results follows the following pattern: We first present the learning theories adopted by the teaching staff and we then move on to their teaching practice. Our findings are presented as a synthesis of the material gathered from all our research tools. We labeled S1 for interview Subject 1, S2 for Subject 2 and so on.

\subsection{Learning Theories Adopted by the Teaching Staff}

\subsubsection{Views on Education, Quality Teaching and Learning}

University teachers consider that the ultimate goal of education, beyond 'providing knowledge' (S4, S5, S6, S7), is '...the cultivation of students' intellect/cognition'(S5), 'improvement of the learners' skills'(S3), 'social inclusion, occupational integration and adaptation to the ever-evolving social and technological conditions'(S1).

University teachers define learning as: 'the integration of knowledge into the learner's value system and tacit knowledge, which when called upon will support the so-called "skillful act"(S1), $\ldots$ the process of incorporating new concepts and of practically implementing new things/knowledge'(S3), ‘..the acquisition of knowledge and the impetus for further research'(S6). Students learn when they '...improve on a certain subject, change the way they views things, or organize them better in their minds'(S2), ‘...acquire knowledge, skills, behaviors and values'(S5), '... achieve the goals set for the program they attend'(S7).

The quality of education is influenced by a number of factors related to the people involved in the learning process (teachers and students) and with conditions that are institutionally and independently determined. Some indicative answers regarding these factors are: 'trainers, training conditions, access to reliable information'(S1), 'The participants' character and desires'(S2), 'The level of the instructor, the means used'(S3), 'the self-esteem the teacher should have'(S4), 'the central educational policy', '...the environment (infrastructure) of the educational organization'(S5), '...the lack of specialization'(S6), $'$...the planning, the number of students'(S7).

Quality teaching is defined as teaching that apart from 'providing a high level of knowledge'(S3), 'fulfills the goals set'(S2, S5), 'follows the developments of modern reality'(S7),....provides knowledge through examples and experiential learning'(S6) and is a result of proper preparation. One teacher emphatically mentions: 'quality begins and ends with the teacher. Painstaking preparation is needed and the result should never create a feeling of satisfaction but should always be a cause for improvement'(S4), while another argues: 'quality teaching is about enhancing explicit and insightful knowledge (deep education). It is important to give multimodal and continuous stimuli so that they be perceived in an intense and deep way'(S1). 
4.1.2 University Teachers' Views About Their Role, the Objectives of Adult Education, and Students' Characteristics.

University teachers believe that the goals of adult education are different, at least to some extent, compared to those of under-graduate students. Some of them are: 'vocational training'(S1), 'gaining experience'(S6), 'satisfying the students' different desires'(S2), 'adapting to the special needs adults have'(S7). Moreover, teachers argue that there are differences between adults and undergraduate students that originate from the adults' maturity and plethora of experiences which in turn affect the goals they set.

Moving on to the way they perceive their own role, teachers state that an effective adult teacher should have excellent subject knowledge (S3, S5, S7), arouse students' interest, satisfy students' expectations and goals (S1, S2, S5), be flexible and lead to knowledge through experiential learning (S4, S6).

As part of their role, four of the seven teachers believe that there is a need for ongoing training, either because they do not monitor developments in adult education, or because they view education as a dynamic and ongoing process. The following answer is typical: '...the biggest mistake is the feeling that everything is working properly. Everything is changing and we must follow the facts by participating in them'(S4).

In this section we talked about how teachers approach learning and teaching. In the next we will try to answer the second research question, with the help of a student questionnaire and the observations made during teaching.

\subsection{Teaching in Practice (Methods, Classroom Reality)}

\subsubsection{Questionnaires}

The second research question aims to show if and in what way the theories adopted by teachers are applied to practice. Thus, this section revolves around the students' answers and the observation material.

The majority of the student participants consider the following as the most appropriate teacher roles: supporter, coordinator, guide, collaborator, mentor, instigator. As important qualifications they mention: subject knowledge, transmissibility, positive mood, patience, flexibility, empathy and understanding of students' needs. They also want teachers that promote critical thinking and responsibility and are accessible, open, communicative and innovative.

As far as teaching practice is concerned, the majority of participants (91.9\%) express the view that there was a connection between the knowledge gained and the situations and problems of their daily lives, $6.1 \%$ claim there was a small connection and only $2 \%$ that there was no connection at all.

The majority of students (63.3\%) agree with the proposition that teachers investigated their needs and expectations, $25.5 \%$ are neutral while $11.2 \%$ disagree. The proposition that teachers supported the achievement of individually set goals finds $89.8 \%$ of respondents in agreement, while $10.2 \%$ disagree. The majority $(71.4 \%)$ hold the view that teachers utilized students' knowledge and experience, $23.5 \%$ appear neutral while $5.1 \%$ disagree. The opinion that teachers succeeded in making students understand the way in which learning is achieved is expressed by $70.4 \%$ of students, whereas $23.5 \%$ are neutral and $6.1 \%$ disagree.

In the question regarding the learning experience (knowledge, skills and attitudes acquired) the majority say they have been helped at all 3 levels. However, the highest percentage was recorded in the area of attitudes, which is the ultimate goal of adult education programs (Table 3).

Table 3. The learning experience

\begin{tabular}{lllll}
\hline & $\begin{array}{l}\text { The learning } \\
\text { experience } \\
\text { helped me in } \\
\text { terms of... }\end{array}$ & Knowledge & $\begin{array}{l}\text { Skills (utilizing } \\
\text { and implementing } \\
\text { new knowledge) }\end{array}$ & $\begin{array}{l}\text { Attitudes (review } \\
\text { old and/or adopt } \\
\text { new attitudes) }\end{array}$ \\
\hline Agree & $70.4 \%$ & $68.4 \%$ & $74.5 \%$ \\
\hline Neutral & $26.5 \%$ & $29.6 \%$ & $18.4 \%$ \\
\hline Disagree & & & $7.1 \%$ \\
\hline
\end{tabular}

\subsubsection{Observation}

The purpose of the observation was to obtain a sense and a general picture of the classroom's climate, of the relationship between university teacher and students and to discover if and how the theories that teachers embrace are transferred to their teaching through the practices and methods they use. 
The processing of the observation material shows that many of the requirements of adult and student-centered learning are satisfied in practice. Therefore, the approaches and views of the teaching staff on learning and teaching are transferred to their practice to a degree. The climate during teaching is friendly, familiar and pleasant. The teacher appears approachable, communicative and asks for the students' opinions. He speaks with examples drawn from his personal experience, through which he tries to provoke the students' reflection presenting them with a situation and asking how they would react, to what end and with what possible outcome. He is concerned about the connection between knowledge, reality and the self as well as the acquisition of knowledge not only explicitly but also subconsciously.

The teacher is far from the role of an authority figure. On the contrary, teachers and students interact in a friendly, supportive and respectful way. During the classroom meetings/sessions, students participate when the opportunity arises, ask for clarifications and express their opinion freely and without hesitation.

However, weak points were also detected during the observation. Some of them are practical issues, such as the large number of students, the classroom's layout, the lack of a properly working microphone, and the poor acoustics of the venue. The number of students in combination with the classroom's layout prevented the teacher from arranging the seats in a way that would facilitate the cooperation of students. In addition, the lack of a working microphone in combination with the venue's poor acoustics resulted in time being wasted and in students seated in the back rows resigning as it was hard for them to keep up.

Another issue concerns the use of educational techniques. The student-centered philosophy of the teacher did not translate, to the degree expected, into the use of active teaching techniques. The techniques used in order of frequency (from most to least common) are: enriched presentation, questions-answers, discussion.

\section{Discussion}

The picture outlined by university teachers' responses with regard to the first question is that they do not clearly and solely embrace a specific learning theory but rather pieces of different theories. Their approaches do not constitute a homogenous and undivided body, but each teacher has a personal stance with unique characteristics and differentiations.

Their viewpoints as a whole are in line with humanistic theories. They adopt most of Knowles' assumptions about adult education and agree on the importance of students' active participation (Rogers, 1999). They seem to agree with Jarvis (2004, 2012) and Mezirow $(1981,2009)$ in that students have a certain biography and experiences that influence if /what they learn and how they evaluate the content presented to them. Teachers define learning as: integration of knowledge into students' value system, action supported both by explicit and tacit knowledge (culture, experience, values), knowledge incorporation and implementation of new concepts, change of perspective, acquisition of skills, behavior, and values. However, we notice a distance between the way they perceive learning and the role of education in it. Most mention provision and transfer of knowledge as the ultimate goal of education among other references (cultivation of understanding, skills and social inclusion, adaptation to social/technological changes). The words "provision" and "transfer" when referring to education diminish the students' role in the learning process and seem to present knowledge as something teachers hold and transmit to students.

Critical reflection is considered essential in Higher and adult education both for students and teachers alike (Lundgren \& Poell, 2016; Liu, 2015; Smith, 2011; Brookfield, 2017; Lucas \& Tan, 2013; Watson \& Kenny, 2014; Ryan \& Ryan, 2013). It is a prominent feature of Freire's $(2018)$, Jarvis' $(2004,2012)$ and Mezirow's $(1981,1990,2009)$ theories though it is approached differently in each theory. In our case critical thinking is mostly implied in the answers of the teachers [integration of knowledge into the learner's value system (S1), incorporation of new concepts, practical implementation of new knowledge (S3), change in the way one views things (S2), acquisition of new behaviors and values (S5)] and never explicitly stated as a goal or element of teaching. It resembles Jarvis' (2004) critical reflection as presented in his cycle of learning process where it is used by students to evaluate the new content based on their socially structured experiences and preconceived notions. The new content is then accepted, rejected or modified. Mezirow (n.d.) however, argues that critical reflection should question and transform-if needed-these very experiences and reference frames and not just use them as a basis for the evaluation and critique of the new content and experience, while Freire's critical reflection aims for social change/transformation. Freire's theory (2018) is the one most distant to the opinions of teachers as expressed in this study. This is justified by the fact that Freire's audience had different problems (poverty, illiteracy, extreme sociopolitical contrasts, blatant violence). Our inequalities and injustice are more latent, so action is not applicable in the same way.

University teachers' perspectives as presented above, can be classified as belonging mainly to the person-centered humanistic learning theories, while in respect to the knowledge construction process adhere to the cognitive constructivist approach. Teachers cite personal development and change as goals of education without relating them to the influence of society and its constituents on students and their learning. They adopt Knowles' Andragogy and scratch 
the surface of Jarvis' theory (adaptation to changing reality, teachers' characteristics). Though change of the way one views things and integration of new concepts/knowledge into students' value systems are mentioned by some as goals of the learning process, never are they approached and accomplished through critical reflection, a vital feature of Freire's, Jarvis' and Mezirow's theories. Whatever changes pertain to the individual and aim at growth in terms of personal values, skills and at adaptation to social/technological changes. Learners are viewed not as potential agents of change but as individuals who must adjust to changes that happen without and away from them or as Freire puts it to adapt to what is inevitable (Freire, 2000).

Regarding the second research question we see that teachers' viewpoints are transferred to their practice to a satisfactory degree. Students express their satisfaction with teachers' practices and behaviors which are in line with the principles of adult and student-centered learning (needs' and goals exploration, utilization of experience, boost of confidence, knowledge linked to students' professional reality). All the above address Knowles' assumptions about adult learning and are accepted and internalized in all the theories that followed. Students, in agreement with relevant literature (Nitsiou, 2018; Pavlakis et al., 2013; Su \& Wood, 2012; Trammell \& Aldrich 2016), desire a good relationship with teachers, qualifications that are related to teachers' characters (positive mood, patience, empathy, communication, flexibility) and quality of interaction. Their desire is realized since teachers-students relationship is friendly, harmonious and the interaction takes place in conditions of equality and freedom of expression. The roles assumed by teachers are far from the role of the inaccessible authority figure, a fact in accordance with all the theories mentioned so far. Finally, the majority of students admit that they have progressed at all levels of learning (knowledge, skills, attitudes) and understood the way in which learning is achieved. This claim is important since it means that the meta-cognitive process of reflection occurred in the learning process, a key component of Jarvis $(2004,2012)$ and Mezirow's learning theories. It means that students passed from the descriptive stage of the learning process (what happened) to the explanatory (why, in what way and with what goal).

As far as critical thinking is concerned, it seems that the intention is there. The teacher tried to intrigue students, to provoke thinking by using examples and asking questions. However, there were some practical issues mentioned previously (large number of students, classroom's layout, faulty equipment, poor acoustics) that hindered his efforts. In fact, most concerns articulated by students and teachers are practical and have to do with building restrictions, infrastructure and organizational issues.

One issue that is directly related to the learning process in an educational way, concerns the use of active educational techniques. There is a mismatch between teachers' intentions (student-centered) and their practice (teacher-centered) in terms of use of active teaching techniques. The most common technique in our study is enriched presentation - an improvement from the typical lecture which is the dominant technique in the literature (Dole, et al., 2016; Nitsiou, 2018; Pavlakis et al., 2013; Stearns, 2017). However, since active involvement is important for the quality of teaching and learning, further research is needed in order to create the conditions that promote the use of active teaching techniques.

Moreover, the distance noticed in the teachers' answers when asked about the goal of education and their definition of learning could be further explored. Teachers appoint a broader, almost transformational role to learning, one where culture, values, behaviors, experiences, change come to play, whereas their view on the goals of education is confined to the transmission of knowledge, skills and vocational training. This could be partly explained by the fact that TEIs were higher technological institutions that placed emphasis on providing practical training and applied knowledge of science and technology in the relevant professional fields. It seems as though teachers implicitly acknowledge a difficulty in aligning their perception of learning with the reality of education and their classrooms. Indeed, there are some conditions in the Greek educational environment that complicate their teaching efforts. Greece's student-teacher ratio in tertiary education is the worst among all country members of EU (38,7 students per member of academic staff), with the average EU ratio being 15,3 (eurostat, n.d.). As a result there are classes which accommodate 100-200 students where a personal relationship is very difficult to be established, teachers' work is hindered and less active teaching techniques prevail. As far as the department of the IHU where the research took place is concerned (Department of Business Administration, Marketing and Tourism), we could mention in order to offer some perspective that each year it accepts $\approx 320$ new entrants (edu.klimaka, 2020). Also-as mentioned in the introduction -most Greek universities lack centers for teaching and learning so university teachers are not supported with their teaching, pedagogic and advisory work. There are structural problems in our tertiary education system that need to be addressed in parallel with university teachers' pedagogic training and support.

\section{Conclusion}

Closing, our study reveals that Higher Education teachers seem to understand the challenges that teaching adults in this context entails. They do not appear to embrace and adopt a single theory and they appoint different roles to learning and education. Their practice follows the principles of adult and Higher education as far as the relationship with their 
students is concerned but does not comply, to a satisfactory degree, with the use of techniques that promote active participation. However, students appear satisfied both with the learning process and their relationship with university teachers. An important limitation of the study is the limited observation so there is a need for extensive future observation that will shed more light to the classroom dynamics, the use of techniques and the way beliefs and theory are applied in the classroom context. Another is that the interviews were conducted via Google forms, so much of the non-verbal communication and information was lost, as was the opportunity to ask for clarifications during the interview and while the subject was in a particular frame of mind, concentrated on the issues at hand. Thus, face-to-face interviews should be conducted so as to create a more complete and deep understanding of the way university teachers view teaching and learning in relation to the theories mentioned. Finally, the composition of the teaching staff in the specific institution (100\% Caucasian, 76\% male)-as in most Universities in Greece-limits the perspective of the issue at hand to that of a white male teacher, excluding the perspectives originating from gender, racial or other forms of differences between the university teachers.

University pedagogy constitutes a relatively new research area in Greece. Even so, university teachers seem to understand the overtones of adult and Higher education. They view learning as a dynamic process that can potentially transform the learner and they provide a safe environment and friendly and supportive interactions with students. With regard to the scope of their practice their perceptions are consistent with person-centered humanistic theories. They acknowledge and adopt Knowles' assumptions, but no clear and significant influences of the other theorists can be detected. As far as the knowledge construction process is concerned, we identify the subtle presence of cognitive constructivism. We can trace in their teaching the focus they place on personal development and their acknowledgement of the influence of students' previous experience and learning. The psychological aspect of learning seems to be more evident in their perspectives; this kind of learning is connected to the individual, happens in isolation and remains unaffected by the context (society, ideologies, power). Change is also personal while personal or societal transformation -either progressive (Jarvis, Mezirow) or critical/radical (Freire) - is never stated as a goal. Instead, it is students who have to adapt to the changes that happen around them and knowledge is used as a means towards this end. Teachers' understanding of the role of education moves towards knowledge transmission and vocational training, the latter connected with the nature and mission of the former Technological Institutions (practical training, applied knowledge). A reason for this could be that the country's educational environment is not supportive. The centralized educational system, the lack of centers for teaching and learning and the subsequent lack of pedagogic training, the high student-teacher ratio and the infrastructure problems weigh on teachers' efforts. This, however, does not mean that there is no space for improvement within the present conditions. University teachers should work towards creating a supporting structure -even informal-within the institution and cooperate with other educational institutions in order to promote pedagogic training (workshops, seminars and programs) and foster peer collaboration. However, these efforts must go hand in hand with pressure towards governments to increase education funding, let institutions themselves diagnose their needs and act on them, hire more university teachers, establish learning centers and make pedagogic training a prerequisite for anyone wishing to enter a university classroom and teach.

\section{References}

Alghamdi, A. K., Kayan, F., \& Hattami, A. (2017). Evaluating teaching strategies in higher education from students' perspectives. Journal of Education and Learning, 11(2), 120-129.https://doi.org/10.11591/edulearn.v11i2.5981

Alhija, F. N. A. (2017). Teaching in higher education: Good teaching through students' lens. Studies in Educational Evaluation, 54, 4-12.https://doi.org/10.1016/j.stueduc.2016.10.006

Almarghani, E. M., \& Mijatovic, I. (2017). Factors affecting student engagement in HEIs-it is all about good teaching. Teaching in higher education, 22(8), 940-956. https://doi.org/10.1080/13562517.2017.1319808

Asio, J. M. R., \& Riego de Dios, E. E. (2018). 21st Century Attributes and Skills of a Teacher in the Perspective of College Students. Online Submission.

Asio, J. M. R., \& Riego de Dios, E. E. (2019). The college students' perspective on what makes an educator well-qualified. Journal of Pedagogical Research, 3(3), 126-138. https://doi.org/10.33902/jpr.v3i3.124

Asonitou, S. (2016). The Necessity to Develop University Teachers' Pedagogical Training. A New Institutional Theory Approach. In K. Kedraka (Ed.) Proceedings of the 2016 Symposium for University Pedagogy: Education and Teaching in higher education, a terra incognita? (pp. 120-129). Alexandroupolis, Greece: Democritus University of Thrace. [in Greek]

Bada, S. O., \& Olusegun, S. (2015). Constructivism learning theory: A paradigm for teaching and learning. Journal of Research \& Method in Education, 5(6), 66-70. 10.9790/7388-05616670

Bantiou, M. M. (2014). Investigation of the changes in attitudes and perceptions of adult instructors regarding the 
application of active and participatory teaching techniques after attending the programme "Educating instructors" organised by I.D.E.K.E in Patras in 2011. [Master's Thesis, University of the Peloponnese.] Amitos: University of Peloponnese Repository. http://amitos.library.uop.gr/xmlui/handle/123456789/2838.[in Greek]

Boyer, E. L. (1990). Scholarship reconsidered: Priorities of the professoriate. Princeton University Press, 3175 Princeton Pike, Lawrenceville, NJ 08648.

Brookfield, S. (2005). The Power of Critical Theory for Adult Learning and Teaching. England: Open University Press.

Brookfield, S. D. (2017). Becoming a critically reflective teacher( $2^{\text {nd }}$ ed.) San Francisco: Jossey-Bass.

Bryman, A. (2016). Social research methods. Oxford university press.

Collins, J. B., \& Pratt, D. D. (2011). The teaching perspectives inventory at 10 years and 100,000 respondents: Reliability and validity of a teacher self-report inventory. Adult Education Quarterly, 61(4), 358-375.https://doi.org/10.1177/0741713610392763

Connell, G. L., Donovan, D. A., \& Chambers, T. G. (2016). Increasing the use of student-centered pedagogies from moderate to high improves student learning and attitudes about biology. CBE-Life Sciences Education, 15(1), ar3. https://doi.org/10.1187/cbe.15-03-0062

Dole, S., Bloom, L., \& Kowalske, K. (2016). Transforming pedagogy: Changing perspectives from teacher-centered to learner-centered. Interdisciplinary Journal of Problem-Based Learning, 10(1), 1. https://doi.org/10.7771/1541-5015.1538

Edu, K. (2020) Entrants' Number in Tertiary Education. Retrieved May 5, 2020 from https://edu.klimaka.gr/panelladikes/exetaseis/424-arithmos-eisaktewn-panelladikes-exetaseis.[in Greek]

EHEA Ministerial Conference Bologna (1999). http://www.ehea.info/page-ministerial-conference-bologna-1999

EHEA Ministerial Conference Bucharest

(2012). http://www.highereducation.ac.cy/pdf/bucharest_communique_2012.pdf.

EHEA Ministerial Conference Leuven/Louvain-la-Neuve http://www.ehea.info/media.ehea.info/file/2009_Leuven_Louvain-la-Neuve/93/1/EURASHE_Statement_Leuven_ 22April_final_594931.pdf

EHEA Ministerial Conference Yerevan (2015). Retrieved http://www.highereducation.ac.cy/pdf/2015_Yerevan_Communique.pdf

EKT (2020). Participation of women in Research and Development in Greece. Athens: Documentation Center. https://www.ekt.gr/el/news/23774.[in Greek]

Ertmer, P. A., \& Newby, T. J. (1993). Behaviorism, cognitivism, constructivism: Comparing critical features from an instructional design perspective. Performance improvement quarterly, 6(4), 50-72.https://doi.org/10.1111/j.1937-8327.1993.tb00605.x

Eurostat (n.d.). https://ec.europa.eu/eurostat/statistics-explained/index.php/Tertiary_education_statistics\#Participation_of_men_an d_women_in_tertiary_education

FEK 1832/13.05/2020, Government Gazette Issue B, No. 365/13895. Supplementation of the bylaw of the University of Patras (FEK 3899/25.10.2019, issue B), p.p. 18738-39. [in Greek]

FEK 2468/24.06.2019, Government Gazette Issue B, No. 18/13/16-5-2019.Establishment of a Teaching and Learning Support Office at the Democritus University. [in Greek]

FEK 3933/15.09.2020, Government Gazette Issue B, No. 16138.Establishment of a Teaching and Learning Support Office at the Aegean University. [in Greek]

Freire, P. (2000). Pedagogy of freedom: Ethics, democracy, and civic courage. USA: Rowman \& Littlefield Publishers.

Freire, P. (2005). Education for critical consciousness. London and New York: Continuum.

Freire, P. (2018). Pedagogy of the oppressed (50 ${ }^{\text {th }}$ Anniversary ed.) USA: Bloomsbury Publishing.

Frementiti, E. M. (2018). University teachers' beliefs, objectives and practices regarding teaching and learning: The case of the Ionian University Faculty Members. [Master's Thesis, Hellenic Open University]. Apothesis Repository of the HOU. https://apothesis.eap.gr/handle/repo/37908. [in Greek]

Gioti, L. (2010). Adult Education Philosophies Guiding Educational Theory and Practice: The Case of Greek Primary Education Teacher Counsellors. The International Journal of Learning, 17(2), 
393-406.https://doi.org/10.18848/1447-9494/CGP/v17i02/46853

Gioti, L. (2019a). I Diamórphosi tou Pedíou tis Ekpaídefsis Enilíkon. [The formulation of the field of adult education]. Athens: Grigori. [in Greek]

Gioti, L. (2019b). Theories of Action and Theories-in-use of Adult Educators. Motivation, Obstacles and Individual Differences in Teachers' Training. International Journal of Learning and Teaching, 5(3), 233-239. https://doi.org/10.18178/ijlt.5.3.233-238

Gougoulakis, P. (2016). University Pedagogy in practice. Organisation, support and development of didactic training of University teachers. In K. Kedraka (Ed.) Proceedings of the 2016 Symposium for University Pedagogy: Education and Teaching in higher education, a terra incognita? (pp. 55-73). Alexandroupolis, Greece: Democritus University of Thrace. [in Greek]

Gougoulakis, P., \& Oikonomou, A. (2014). Panepistimiaki Paidagogiki. [University Pedagogy]. Educ@tional Circle, 2(1), 9-48. Retrieved from http://journal.educircle.gr/el/arxeio-tefxon/proigoymena-teyxi/tefxos-2-2014/tomos-2-teyxos-1-2014/19-teyxi-peri odikon/tomos-2-teyxos-1/59-panepistimiaki-paidagogiki. [in Greek]

Gougoulakis, P., Kedraka, K., Oikonomou, A., \& Anastasiades, P. (2020). Teaching in Tertiary Education - A reflective and experiential approach to University Pedagogy. Academia, O(20-21), 101-137. https://doi.org/10.26220/aca.3443.

Grift, W. (2007). Quality of teaching in four European countries: a review of the literature and application of an assessment instrument. Educational Research, 49(2), 127-152. https://doi.org/10.1080/00131880701369651

Halx, M. D. (2010). Re-conceptualizing college and university teaching through the lens of adult education: Regarding undergraduates as adults. Teaching in Higher Education, 15(5), 519-530.https://doi.org/10.1080/13562517.2010.491909

HQA, (2017). Annual Quality Report 2016. July, 2017.https://www.ethaae.gr/en/about-hqa/hqa-anunual-reports.[in Greek]

Illeris, K. (2009). A comprehensive understanding of human learning. In K. Illeris (Ed.), Contemporary theories of learning: learning theorists... in their own words (pp. 7-20). New York: Routledge. https://doi.org/10.4324/9780203870426

Illeris, K. (2016). How we learn: Learning and non learning in school and beyond. (E. Kostara, Trans.). Athens: Metehmio. (Original work published 1999).https://doi.org/10.4324/9781315537382

Illeris, K. 2007. How we learn:Learning and non-learning in school and beyond. New York:Routledge.https://doi.org/10.4324/9780203939895

Ioakeimidou, V., Papadimitriou, S., \& Lionarakis, A. (2015). Investigating the Teaching Experience of Tutors/advisors:A Case Study at the Hellenic Open University. International Conference in Open \& Distance Learning, 8(2A).https://doi.org/10.12681/icodl.92

Jarvis, P. (2004). Adult and Continuing education and training: theory and practice. (A. Maniati, Trans.) Athens: Metaichmio. (Original work published 1995). [in Greek]

Jarvis, P. (2009). Learning to be a person in society: learning to be me. In K. Illeris (Ed.), Contemporary theories of learning: learning theorists... in their own words (pp. 21-34). New York: Routledge.

Jarvis, P. (2012). Adult learning in the social context. London: Routledge. https://doi.org/10.4324/9780203802724

Kedraka, K., \& Rotidi, G. (2017). University Pedagogy: A New Culture Is Emerging in Greek Higher Education. International Journal of Higher Education, 6(3), 147-153. https://doi.org/10.5430/ijhe.v6n3p147

Kedraka, K. (2016). University Pedagogy: Past, Present and Future. In K. Kedraka (Ed.) Proceedings of the 2016 Symposium for University Pedagogy: Education and Teaching in higher education, a terra incognita? (pp. 21-39). Alexandroupolis, Greece: Democritus University of Thrace. [in Greek]

Kedraka, K., \& Dimasi, M. (2015). Teaching in Higher Education: Obligation, chore or privilege? In S. Kioulanis, A. Pashalidou, Z. Harpantidou (Ed.) Proceedings of the $1^{\text {st }}$ International Experiential Conference on Applied Teaching.

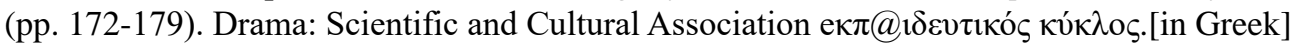

Knowles, M. (1990). The adult learner: a neglected species. (4 $4^{\text {th }}$ ed.) Texas, Gulf Publishing Company.

Knowles, M. S., Holton III, E. F., \& Swanson, R. A. (2005). The adult learner: The definitive classic in adult education and human resource development (6th ed.). San Diego, CA: Elsevier 
Law No. 4610/2019, Government Gazette, FEK 70/A/752019:Synergies of Universities and TEIs, access to higher education, experimental schools, General State Archives and other provisions. [in Greek]

Law No.4009, Government Gazette, FEK A 195/6.9.2011/Issue A.: Structure, function, quality assurance of studies and internationalization of higher education institutions. [in Greek]

Leonard, P., \& McLaren, P. (Eds.). (2002). Paulo Freire: A critical encounter. London and New York: Routledge. https://doi.org/10.4324/9780203420263

Lindblom-Ylänne, S., Trigwell, K., Nevgi, A., \& Ashwin, P. (2006). How approaches to teaching are affected by discipline and teaching context. Studies in Higher Education, 31(03), 285-298.https://doi.org/10.1080/03075070600680539

Liu, K. (2015). Critical reflection as a framework for transformative learning in teacher education. Educational Review, 67(2), 135-157 https://doi.org/10.1080/00131911.2013.839546

Lucas, U., \& Tan, P. L. (2013). Developing a capacity to engage in critical reflection: students' 'ways of knowing' within an undergraduate business and accounting programme. Studies in Higher Education, 38(1), 104-123. https://doi.org/10.1080/03075079.2011.569706

Lueddeke, G. R. (2003). Professionalising teaching practice in higher education: A study of disciplinary variation and 'teaching-scholarship'. Studies in higher education, 28(2), 213-228.https://doi.org/10.1080/0307507032000058082

Lundgren, H., \& Poell, R. F. (2016). On critical reflection: A review of Mezirow's theory and its operationalization. Human Resource Development Review, 15(1), 3-28. https://doi.org/10.1177/1534484315622735

Lynch, R. P., \& Pappas, E. (2017). A Model for Teaching Large Classes: Facilitating a "Small Class Feel". International Journal of Higher Education,6(2), 199-212.https://doi.org/10.5430/ijhe.v6n2p199

Magos, K. (2005). Sinéntefxi í Paratírisi: I Érevna sti Skholikí Táxi [Interview or observation]. Research in the school classroom. Review of Educational Issues, 10, 5-19. http://www.pi-schools.gr/publications/epitheorisi/teyxos10/. [in Greek]

McGrath, V. (2009). Reviewing the Evidence on How Adult Students Learn: An Examination of Knowles' Model of Andragogy. Adult Learner: The Irish Journal of Adult and Community Education, 99, 110.

Mezirow, J. (1981). A critical theory of adult learning and education. Adult education, 32(1), 3-24.https://doi.org/10.1177/074171368103200101

Mezirow, J. (1990). A transformation theory of adult learning. In P. Kleiber, L. Tisdell (Ed.) Proceedings of Annual Adult Education Research Conference, (pp. 152-157) Athens: Georgia University. https://files.eric.ed.gov/fulltext/ED357160.pdf\#page=153.

Mezirow, J. (2009). An overview on transformative learning. In K. Illeris (Ed.), Contemporary Theories of Learning (pp. 90-105). New York: Routledge.

Mezirow, J. (n.d). Fostering critical reflection in adulthood. March 20, 2019 from https://my.liberatedleaders.com.au/wp-content/uploads/2017/02/How-Critical-Reflection-triggers-TransformativeLearning-Mezirow.pdf

Nikolakoudis, A. (2016). Comparative Study on the role of the adult educator in technical and theoretical Institutes of Vocational Training (I.V.T.) in the district of Thessaloniki. [Master's Thesis, Hellenic Open University]. Apothesis Repository of the HOU. https://apothesis.eap.gr/handle/repo/32950.[in Greek]

Nitsiou, C. (2018). The role of the teacher of postgraduate programs as an adult educator. The case of a School of the Aristotle University of Thessaloniki. [Master's Thesis, Hellenic Open University]. Apothesis Repository of the HOU. https://apothesis.eap.gr/handle/repo/39378[in Greek]

Osman, S. Z. M., Jamaludin, R., \& Iranmanesh, M. (2015). Student Centered Learning at USM: What Lecturer and Students Think of This New Approach?. Journal of Education and Practice, 6(19), 264-277.

Pasiardis, P. (2001). Pasiardis' evaluation form. Retrieved April 28, 2019 from http://www.moec.gov.cy/dde/anaptyxi_veltiosi_scholeiou/poiotita_didaskalias_mathisis.html[in Greek]

Pavlakis, A., Talias, M., \& Zannetos, S. (2013). Contact Sessions at the Open University of Cyprus: Views of the students of the Postgraduate Program "Health Care Units Management". International Conference in Open and Distance Learning, 7(5B). https://doi.org/10.12681/icodl.557

Perkins, D. N. (1991). What constructivism demands of the learner. Educational technology, 31(9), 19-21. Retrieved Aril 6, 2021, from http://www.jstor.org/stable/44401693 
Pratt, D. D., \& Collins, J. B. (2000, June 2-4). The teaching perspectives inventory (TPI).In Adult Education Research Conference, Vancouver, BC, Canada

Pratt, D. D., Collins, J. B., \& Selinger, S. J. (2001, April). Development and use of the Teaching Perspectives Inventory (TPI). In Annual meeting of the American Educational Research Association, Seattle Washington.

Pritchard, A. (2009). Ways of learning ( $2^{\text {nd }}$ ed.). New York: Routledge. https://doi.org/10.4324/9780203887240

Prosser, M., \& Trigwell, K. (2014). Qualitative variation in approaches to university teaching and learning in large first-year classes. Higher Education, 67(6), 783-795. https://doi.org/10.1007/s10734-013-9690-0

Rogers, A. (1999). I Ekpaídefsi Enilíkon. [Adult Education]. Metaichmio.

Rotidi, G, \& Karalis, T. (2014). Reflection on teaching in higher education: Critically reflective processes of Greek academics in hard, soft, pure and applied disciplines. In D. Andritsakou, L. West (Eds.) Proceedings of the $1^{s t}$ Conference of ESREA's Network "“Interrogating Transformative Processes in Learning and Education: An International Dialogue". Athens, Greece: ESREA \& Hellenic Adult Education Association (pp. 338-350). Athens, Greece: ESREA \& Hellenic Adult Education Association.

Rotidi, G, (2015). Teaching perspectives and critically reflective processes of academics in higher education: a quantitative and qualitative research based on TPI (Teaching Perspectives Inventory), Biglan's taxonomy of academic disciplines and the SofT (Scholarship of Teaching) model. [Doctoral Dissertation, University of Patras]. Nemertes. http://hdl.handle.net/10889/9271. [in Greek]

Ryan, M., \& Ryan, M. (2013). Theorising a model for teaching and assessing reflective learning in higher education. Higher Education Research \& Development, 32(2), 244-257. https://doi.org/10.1080/07294360.2012.661704

Schunk, D. H. (2012). Learning theories an educational perspective sixth edition. Pearson.

Smart, K. L., Witt, C., \& Scott, J. P. (2012). Toward learner-centered teaching: An inductive approach. Business Communication Quarterly, 75(4), 392-403. https://doi.org/10.1177/1080569912459752

Smith, E. (2011). Teaching critical reflection. Teaching in higher education, 16(2), 211-223. https://doi.org/10.1080/13562517.2010.515022

Stearns, S. (2017). What is the place of lecture in student learning today?. Communication Education, 66(2), 243-245. https://doi.org/10.1080/03634523.2016.1275723

Stergiou, D. P., \& Airey, D. (2012). Using the Course Experience Questionnaire for evaluating undergraduate tourism management courses in Greece. Journal of Hospitality, Leisure, Sport \& Tourism Education, 11(1), 41-49.https://doi.org/10.1016/j.jhlste.2012.02.002

Stetsenko, A., \& Arievitch, I. (1997). Constructing and deconstructing the self: Comparing post-Vygotskian and discourse-based versions of social constructivism. Mind, Culture, and Activity, 4(3), 159-172. https://doi.org/10.1207/s15327884mca0403_3

$\mathrm{Su}$, F., \& Wood, M. (2012). What makes a good university lecturer? Students' perceptions of teaching excellence. Journal of Applied Research in Higher Education. https://doi.org/10.1108/17581181211273110

Sursock, A. (2015). Trends 2015: Learning and Teaching in European Universities. European university association.

Tennant, M. (1986). An evaluation of Knowles' theory of adult learning. International Journal of Lifelong Education, 5(2), 113-122.https://doi.org/10.1080/0260137860050203

Trammell, B. A., \& Aldrich, R. S. (2016). Undergraduate Students' Perspectives of Essential Instructor Qualities. Journal of the Scholarship of Teaching and Learning, 16(1), 15-30.https://doi.org/10.14434/josotl.v16i1.19178

Trent, S. C., Artiles, A. J., \& Englert, C. S. (1998). From deficit thinking to social constructivism: A review of special education theory, research and practice. Review of Research in Education,23(1), 277-307. https://doi.org/10.3102/0091732X023001277

Tzotzou, M., \& Bigilaki, N. (2013). Investigation of students' views attending the postgraduate programme "Studies in Education" about distance individualised learning at the HOU-A case study. Open Education -The Journal for Open and Distance Education and Educational Technology, 9(1), 75-93.https://doi.org/10.12681/jode.9803[in Greek]

Uiboleht, K., Karm, M., \& Postareff, L. (2018). The interplay between teachers' approaches to teaching, students' approaches to learning and learning outcomes: a qualitative multi-case study. Learning Environments 
Research, 21(3), 321-347. https://doi.org/10.1007/s10984-018-9257-1

Vergidis, D. (2016). University Pedagogy, quality assurance and the role of the University Teachers. In K. Kedraka (Ed.) Proceedings of the 2016 Symposium for University Pedagogy: Education and Teaching in higher education, a terra incognita? (pp. 74-89). Alexandroupolis, Greece: Democritus University of Thrace

Watson, G. P. L., \& Kenny, N. (2014). Teaching critical reflection to graduate students. Collected essays on learning and teaching, 7(1), 56-61 https://doi.org/10.22329/celt.v7i1.3966

\section{Copyrights}

Copyright for this article is retained by the author(s), with first publication rights granted to the journal.

This is an open-access article distributed under the terms and conditions of the Creative Commons Attribution license which permits unrestricted use, distribution, and reproduction in any medium, provided the original work is properly cited. 